\title{
Freedom of Religion — The Missing Commandment?*
}

\author{
JÖRG PAUL MÜLLER
}

Human rights relate to specific areas of human existence which are characterised by two features. On the one hand they are of central importance in affirming an individual's value and identity and in articulating basic human needs. On the other hand, history shows that these rights stand in latent conflict with state authority, since they pose a barrier to the uninhibited wielding of this authority and set forth relentlessly sprouting seeds of opposition. For this reason, no totalitarian regime can accept healthy human rights, neither freedom of expression nor equality under the law; even in a strong democracy, there are ceaseless confrontations between the will of the majority and the obstinate opposition of fundamental human rights.

Since man experiences his beliefs as the nucleus of his being and is constantly threatened in this experience by the assertion of power by the state or other social authorities, we find one or more forms of religious freedom in all comprehensive declarations on human rights.' This fact reflects the historical experience that human beings are as vulnerable in their religious convictions and practices as in their physical or psychological integrity. The charters of fundamental rights as documents of mankind's learning processes reflect, in their guarantees of freedom of religion, the experience that there is a permanent temptation for political power to intrude upon an individual's innermost convictions and to stabilise itself by coercing people to give up their diverse beliefs in favour of a more uniform and homogeneous religion. Even antiquity teaches that power can be certain only if it subjugates man in his very being - including his religious beliefs - and thus attempts to lame his basic potential to oppose authority: an emperor proclaimed his conquest of foreign territories by destroying the gods and temples of the conquered. In the temples of modern Tibet, you can still see the plucked-out eyes of Buddhas and empathise with the pain and the humiliation, the fear and the horror that the conquered people must have felt at the desecration of their symbols.

The temptation of every regime to consolidate its power through appropriation and control of the religious dimension of human life is a reflex, a mirror of the fundamental importance of the religious perspective for the individual and collective ${ }^{2}$ human reality. The German-American theologian Paul Tillich describes belief as 'man's innermost devotion to the ultimate's demands of him' ('das Ergriffensein des Menschen von dem, was uns unbedingt angeht'). ${ }^{3}$ Belief is an act by the entire per-

*This article was the keynote address at the first seminar on religious freedom convened by the Organization for Security and Co-operation in Europe (OSCE), Warsaw, April 1996. 
son, belief occurs in the centre of an individual's life and embraces all its structures. ${ }^{4}$ Certainly, the state cannot be indifferent to belief understood in this way. The ultimacy of legal claims rivals the ultimacy of belief.

The state's claim to power can actually benefit from uniformity of religion. Religious homogeneity strengthens the cohesion of state unity, renders people more predictable and provides for the increased chance of obedience to religiously-motivated law. But if the price of such harmony is violence towards, or the eradication of, those of a different faith, be they whole groups or particular individuals, the benefit is unjust, wrongful, inhuman, and violative of human rights.

The reinforcement of a state's claim to legitimacy by religious conviction need not necessarily, however, be the result of gross subjugation or manipulative misuse of religious convictions and traditions for political purposes. The state's interests in religious homogeneity and in political apathy can fatally merge with basic human needs for harmony, for safety, stability and social belonging. Such a merger can become fatal if human faith is deflected from the ultimate, or unconditional, toward the conditional. In this case, the latter may be the greatness and honour of a particular nation, the supremacy of a particular race, the charisma of a particular dictator's display of power or the legitimising ideology of a particular ruling class: these are the phenomena on which 'believers' may focus their unconditional belief and in doing so lend them the emotional support of the masses.

Modern psychology teaches that human beings may have a tendency, often unconscious, to subjugate themselves willingly if they are confronted with claims to power which they perceive as unavoidable. They may justify this subjugation with good reasons or they may be willing to identify with false prophets whom they allow to defend it: the subjugated individuals may thereby delude themselves that their obedience is voluntary. This illusion may be necessary for the individual to maintain his or her dignity in the face of inescapable power. This so-called 'identification with the aggressor' (Anna Freud ${ }^{5}$ ) is an insidious mechanism inducing feelings of belonging. Simultaneously, it veils power with ideology. We are familiar with this phenomenon from accounts by the silent participants and the active supporters of totalitarian regimes and total (all-encompassing) institutions, ${ }^{6}$ by wardens of concentration camps and - more disturbingly - even by some inmates. ${ }^{7}$

Is there a way of transcending this tension whereby individual freedom must constantly be reasserted to challenge the lulling temptations of the totalitarian?

I see one way: each believer in an ultimate truth needs to recognise that his or her conception of that truth might in fact be largely determined by culture, by the social environment, by the necessarily limited perspectives of personal intellectual and emotional experiences. An individual who believes in an absolute must admit, as a human being, that the possibility exists that he or she has failed to grasp it in all its comprehensiveness and complexity, that it surpasses his or her imagination, logical thinking and ability to love; that it is truly transcendent and all-encompassing. Tolerance thus ceases to be merely an opportunistic concession, but becomes a sign that I am aware of a comprehensiveness that transcends the realm of my perceptible existence; it is in this that the greatness of tolerance is revealed.

The theologian Hans Küng undertook in his project 'Weltethos'8 to find a common denominator among the variety of religions that could, as a type of religiously motivated minimal ethics, secure the ties that enable us to live together and to realise the 
worldwide cooperation that is so indispensable today. We have to acknowledge the courage of an attempt like this, an attempt that ventures to address the global interdependence of human beings in those questions central to their survival, an attempt that builds on existing religious beliefs to renounce violence and to foster a willingness for global discourse on questions of paramount importance to human survival. Is it not a realistic aspiration to affirm universally valid human values, seeing the urgency with which Islam describes the mercy of Allah, with which Judaism reveres charity, with which Christianity promotes love of one's enemies, with which Buddhism honours sympathy and compassion? The god of any faith can, in my opinion, only be a god that wants human beings to survive, that wants its creatures to remain whole and undeformed by contamination, that wants a home for all, rather than the expulsion or persecution of entire populations. All religious communities, even the major religions of the world, have become minorities as a result of today's increasingly porous borders and the facilitation of communication and travel. Composed of human beings, these congregations existentially rely on a mutual minimal regard for human life.

We can go further. There may be an additional approach to universal ethics that today's mutual dependence and the common fate of man categorically mandate. As well as looking for commonality in a multitude of religious convictions, we ought also to focus on the differences. Seeing differences can be a constructive recognition of the variety inherent in life itself. Plurality is the social expression of this diversity. Suppressing it goes along with contempt for life. The destiny of human existence ultimately seems to lie in differentiation and in maintaining heterogeneity. It is people like you and me, capable of joy and suffering and with the need to make sense of existence, who pray in Hindu temples and in Muslim mosques, who go to confession in Roman Catholic churches and who take communion in Lutheran churches. We are all looking for access to something transcendent and are, as human beings, vulnerable in this intimate search. An insight into those differences that are inherent in the beliefs of people created as equals could open our eyes to the peace-building function of tolerance on which the human right of freedom of belief and religion calls.

The demand for coexistence among the many beliefs in a world where violence has become irrevocably, as a consequence of modern war technologies, an existential global threat to mankind, appears to be unconditional, if one in any way accepts that life and human existence make some ultimate sense. Furthermore, there may be an even deeper significance in the call for tolerance. Each conviction - in order to prevent it from becoming totalitarian - may need the friction caused by contact with opposing beliefs. The encounter with beliefs different from our own could strengthen the insight that even in the search for ultimacy we are limited. Abraham, the 'father of belief', the prophet, the source of many important streams of faith of belief, affords a good example: he did not close his mind to the foreign king Abimelech, who made known to him his own experience with god, proffered a new view which modified Abraham's prior understanding of the godless and therefore dangerous foreigners, and offered reconciliation.' What a richness it would be if we also could make the multiplicity of those experiences with god that are foreign to us fruitful to the end of liberating us from our necessarily narrow historical ideas and experiences. We need others in order that our own convictions and ideas shall not become inhuman, totalitarian or fundamentalist.

\section{III}

International conventions and other documents depend, as do democratic constitu- 
tions, on social preconditions that they themselves cannot ensure. Ultimately, the effectiveness of fundamental rights cannot be secured by normative texts; the members of a legal community must share a basic conviction that for a peaceful communal life free of violence, respect for those rights is indispensable ${ }^{10}$ Freedom of belief and religion, too, exists as a social reality only out of a practised tolerance among citizens as well as among and within various religious communities. What matters is the readiness of every person to accept the dignity of every other individual especially in his or her choice of belief or view of the world.

It is also true, of course, that a culture of tolerance and mutual respect presupposes historical learning processes, however painful, within states, religious communities and in individual lives.

My own country, Switzerland, was torn by religious strife and threatened by internal violence in the last century; a readiness for peaceful coexistence amongst different confessions was achieved only step by step. The process of growing insight into the possibility of political cooperation despite religious plurality and an accompanying development of the required institutions took decades. In this, Switzerland's federal structure was of primary importance. Federalism still allows for the 26 cantons to regulate the relationship of their political authorities to the churches and other religious communities on their own. Some cantons follow the American or French example, with strict separation of church and state; others provide for recognition by the state - for example in the right to collect taxes - of one, or sometimes three or four, religious communities. The Federal Constitution guarantees as a minimum the freedom from any coercion to worship" and requires religious neutrality in all public grade schools. ${ }^{12}$ The precarious peace that was achieved between the Roman Catholics and the Protestants in Switzerland in the nineteenth century was of such urgent concern to our history that the rights of other religious communities lay unattended for a long time; freedom of religion for Jews and other non-Christians was first provided for in 1874 under economic pressure from France, and in 1992 our Federal Court had to order the Zürich authorities to permit imprisoned Muslims the opportunity to congregate for Friday prayers under the instruction of an imam. ${ }^{13}$ This case exemplifies the increasing problems in traditionally Christian Western European societies with non-Christian faiths. ${ }^{14}$ I hope that the often violent clashes between the Christian confessions in Europe during past centuries have given us guidelines which will enable us to deal more humanely with this new potential for religious strife.

The Catholic Church has taken steps of historical significance. The experiences of National Socialism and Stalinist Marxism and their rejection of any form of religion convinced the leadership of the Church to look at the significance of freedom of religion from a new angle. ${ }^{15}$ The insight prevailed that - in the words of Cardinal Franz König of Austria - 'the primacy of truth over freedom collapses the moment human freedom ceases to exist'. ${ }^{16}$ After difficult negotiations, the second Vatican Council in 1965 recognised religious freedom in a comprehensive sense for each person and belief ${ }^{17}$ and at the same time admitted that its own Church had not always observed this freedom. One remembers the abhorrent violations of human dignity during the Inquisition. The Council's clear acknowledgment of religious freedom has subsequently permitted the Church to defend this principle on the international level, as in the formulation of the CSCE Helsinki Final Act in $1975 .{ }^{18}$ With this achievement, the Catholic Church has contributed substantially to respect for human beings and the securing of peace. 


\section{IV}

Learning processes on individual, political and religious-institutional levels are necessary to breathe life into the freedoms of belief and conscience that are proclaimed and declared as binding by international law. We must not forget, however, that religious freedom always depends on the defence of other human rights such as the protection of privacy, freedom of expression and the right to political participation. The religious minority that cannot articulate its specific needs in a democratic process shaping law and state - for example the structure of schools or of labour relations - remains threatened and endangered in respect of its belief. Neither should we forget the connection between liberal individual rights - that is the rights of the person against state incursion - and economic rights. We know from recent history how the breakdown of solidarity within a community can make the negatively affected populations susceptible to religious fanaticism. The upsetting of religious convictions, tilting them into fundamentalist intolerance, even violence, may be the result of long-suppressed misery and social injustice. Economic and political impotence can find - to a certain extent understandably so - compensation in delusions of religious omnipotence. Religious zeal can take on the character of blind escape from experienced misery. Freedom of religion - like any freedom - contains within it an explosive potential that can have fatal consequences. The political and legal programme of freedom can flourish only in the framework of a legal and political environment in which each person and each group is taken seriously in the entirety of its needs, be they spiritual, material or political.

\section{Notes and References}

Freedom of religion is provided for in Article 18 of the Universal Declaration of Human Rights of 10 December 1948, in Articles 18 and 27 of the UN Covenant on Civil and Political Rights of 19 December 1996, in Article 9 of the European Convention for the Protection of Human Rights and Fundamental Fredoms of 4 November 1950, in Article 12 of the American Convention on Human Rights of 22 November 1969, and in Article 8 of the African Charter on Human and Peoples' Rights of 26 June 1981. See also Principle VII, Sections 1 and 3 in the Helsinki Final Act of 1 August 1975 and the reaffirmation of freedom of religion in the documents of the CSCE Follow-up Meetings ('Human Contacts'). The guarantee of freedom of religion and belief is also affirmed by various conventions addressing discrimination on the basis of ethnicity, language or religion and those on minority protection. See for example the UN Declaration on the Elimination of All Forms of Intolerance and of Discrimination Based on Religion or Belief of 25 November 1981, the UN Declaration of Rights of Persons Belonging to National or Ethnic, Religious and Linguistic Minorities of 18 December 1992, and the European Council Framework Convention for the Protection of National Minorities of 10 November 1994.

2 All international guarantees of freedom of religion take account of its collective aspect. Generally, they protect the right of the individual to manifest his or her religion and beliefs 'in community with others, ... in worship, observance, practice and teaching' (CCPR Article 18). In addition to this individual right, the collectivity itself is indirectly protected by some treaties: see for example, CCPR Article 27. Group rights as such, however, have only minimally been recognised on an international level. Certain approaches toward group rights can be found, for example, in Article 1, Section 1 of the UN Declaration of 1992 (see note 1), which requires states to 'protect the existence and the national or ethnic, cultural, religious and linguistic identity of minorities within their respective territories', and to 'encourage conditions for the promotion of that identity'. This provision recognises that minorities as such have legal personality. See Peter Hilpold, 'Minderheitenschutz im 
Rahmen der Vereinten Nationen - Die Deklaration vom 18. Dezember 1992', Schweizerische Zeitschrift für internationales und europäisches Recht (SZIER), no. 49, 1994.

3 Paul Tillich, Wesen und Wandel des Glaubens (Berlin, 1961), p. 9 (quote translated from German edition; American edition: Paul Tillich, The Dynamics of Faith (New York, 1957). op. cit., p. 12.

5 Schriften der Anna Freud (Munich, 1980), vol. 10. Anna Freud describes this phenomenon with respect to children: the humiliated child shows an inclination to justify the superior and unavoidable aggressor, whereas it ought to perceive the 'assault' as unintelligible and intolerable (op. cit., pp. 2781, 2843). See also J. Laplanche and J.-B. Pontalis, Vokabular der Psychoanalyse (Frankfurt am Main, 1973), p. 224: 'The individual ... identifies itself with the assailant either by blaming itself for the aggression, or by imitating the attacker physically or morally or by appropriating certain symbols of power characteristic of him' (my translation - JPM).

6 'Total' institutions regulate and control all aspects of an individual's life comprehensively, to condition him or her for the purpose of the institution. See Grubitzsch and Rexilius (eds), Psychologische Grundbegriffe (Reinbek, 1987), p. $494 \mathrm{ff}$. and particularly p. $1129 \mathrm{ff}$.

, See the impressive account in Barrington Moore, Injustice: The Social Bases of Obedience and Revolt (White Plains, NY, 1978). See also Bruno Bettelheim, Aufstand gegen die Masse: Die Chance des Individuums in der modernen Gesellschaft (Munich, 1964).

\& Hans Küng, Projekt Weltethos (Munich, 1990). In a response to this book, on 4 September 1993 in Chicago the Parliament of World Religions passed a 'Declaration of a Global Ethic', in which people with entirely different religious backgrounds and traditions agreed on a minimal global ethic that was, in their view, indispensable for human survival. See Hans Küng and Karl-Josef Kuschel (eds), Erklärung zum Weltethos: Die Deklaration des Parlaments der Weltreligionen (Munich, 1993). In his latest book on the project of a global ethic, Hans Küng has published numerous statements on the 1993 Declaration by Jewish, Christian, Islamic, Buddhist and Confucian believers. See Hans Küng (ed.), Ja zum Weltethos: Perspektiven für die Suche nach Orientierung (Munich, 1995). For the English text of the declaration see http://www.crc.ricoh.com/ rowan/CTS/ethic.html.

9 Genesis 20.

10 I elaborate on this idea more thoroughly in my book Demokratische Gerechtigkeit: Eine Studie zur Legitimität rechtlicher und politischer Ordnung (Munich, 1993), p. 20 ff. I focus on the dialectical relation between a constitutional consensus and a political structure (op. cit., p. 26 ff). See also Konrad Hesse, Grundzüge des Verfassungsrechts der Bundesrepublik Deutschland, 20th edn (Heidelberg, 1995). Section 41: 'The Constitution consists of norms: they formulate demands on human behaviour, not this behaviour itself; they remain a dead letter if the content of those demands does not actuate human behaviour'. The normative effectiveness of the Constitution 'depends on the topical will of all participants in democratic life to accomplish the contents of the Constitution'.

1 Article 49, Section 2 of the Swiss Federal Constitution. The prohibition of coerced worship and belief constitutes the core content of freedom of religion that may not be infringed under any circumstances.

12 Article 27, Section 2 of the Swiss Federal Constitution. The Swiss Federal Court held in its decision Community of Cadro $v$. Bernasconi and Administrative Court of the Canton of Ticino of 26 September 1990 (BGE 116 1a 25) that a state regulation mandating the hanging of crucifixes on the walls of classrooms in grade schools violated the principle of state neutrality. The German Constitutional Court came to a similar result in its decision of 16 May 1995 (EuGRZ 1995, 359). The US Supreme Court has developed extensive case-law on questions of state neutrality in religious matters: see for example, Lee $v$. Weisman, 505 US 577 (1992) (including clerical members who offer prayers as part of the official school graduation ceremony violates the Establishment Clause of the First Amendment to the US Constitution).

13 Decision Nehal Ahmed Syed $v$. Department of Justice of the Canton of Zürich, 13 November 1987 (BGE 113 1a 304). 
14 The following cases are illustrative of this problem: in BGE 119 1a 178 (EuGRZ 1993, 400) the Swiss Federal Court decided that an Islamic girl was exempt from mandatory swimming classes in grade school because her religion prohibited her from exposing her body. The Federal Administrative Court of Germany handed down a similar decision on 25 August 1993 (BVerwGE 94, 82). See also, for the United States, Mitchell v. McCall, 273 Ala. 604, 143 So. Ct. 629 (1962). In the case-law of the US Supreme Court the following decisions are characteristic for today's religious pluralism: Board of Education of Kiryas Joel Village School District $v$. Grumet, 114 S. Ct. 2481 (1994) (creating a separate school district for a religiously homogeneous village violates the Establishment Clause of the First Amendment to the US Constitution); Church of the Lukumi Babalu Aye $v$. City of Hialeah, 113 S. Ct. 2217 (1993) (a city's ban on 'ritual slaughter' that is directed at the practices of the Santeria religion violates the Free Exercise Clause of the First Amendment to the US Constitution).

is See Cardinal Franz König, 'Religionsfreiheit und Gewissensfreiheit', in Franz Matscher (ed.), Folterverbot sowie Religions- und Gewissensfreiheit im Reichtsvergleich (Kehl am Rhein/Strasbourg/Arlington, VA, 1990), p. 19.

16 op. cit., p. 20.

17 Dignitatis humanae, 7 December 1965.

18 Freedom of religion is the only human right expressly provided for and defined in detail by the Helsinki Final Act. This would probably not have been so without the participation of The Holy See. See Otto Kimminich, Religionsfreiheit als Menschenrecht: Untersuchung zum gegenwärtigen Stand des Völkerrechts (Mainz/Munich, 1990), p. 161 ff. Freedom of religion also played a special part in the CSCE Follow-up Meetings. At the Vienna Meeting the Holy See pressed for the strengthening of human rights, especially of freedom of religion. Principles 16 and 17 of the Concluding Document of the Vienna Meeting are particularly noteworthy: under the title 'Questions Relating to Security in Europe' they reveal the clear connection between freedom of religion and the securing of peace.

(Edited version of a translation from the German by Krista Nadakavukaren and Markus Schefer) 